\title{
A Quantitative Inquiry into the Effects of Blended Learning on English Language Learning: The Case of Malaysian Undergraduates
}

\author{
Siew Ming Thang ${ }^{1}$, Rosniah Mustaffa ${ }^{1}$, Fook Fei Wong ${ }^{1}$, Noorizah Mohd. Noor ${ }^{1}$, Najihah Mahmud ${ }^{1}$, Hafizah \\ Latif $^{1} \&$ Mohd. Sallehhudin Abd. Aziz ${ }^{1}$ \\ ${ }^{1}$ School of Language Studies and Linguistics, Universiti Kebangsaan Malaysia, Selangor, Malaysia \\ Correspondence: Siew Ming Thang, School of Linguistics and Language Studies, Universiti Kebangsaan \\ Malaysia, 43600 UKM Bangi, Selangor, Malaysia. Tel: 60-389-216-499. E-mail: thang@ukm.my
}

Received: February 7, 2013 Accepted: February 25, 2013 Online Published: May 13, 2013

doi:10.5539/ies.v6n6p1

URL: http://dx.doi.org/10.5539/ies.v6n6p1

\begin{abstract}
Blended learning has been described as a pedagogical approach that combines effectiveness and socialization opportunities of the classroom with the technologically enhanced active learning possibilities of the online environment (Dziuban, Hartman, \& Moskal, 2004). It has also been depicted as an approach that combines traditional learning with web-based online approaches (Whitelock \& Jefts, 2003). To what extent are these claims? This study shares the findings of a research project that investigates the use of blended learning in the teaching of English for Academic Purposes to nine classes of students from the Faculty of Social Sciences at Universiti Kebangsaan Malaysia. The blended approach comes in the form of a new course book with a supporting online component. A quantitative approach involving the use of a questionnaire survey was used to find out if the blended approach has benefited the students in terms of meeting their language and personal needs. The findings revealed that the students viewed this approach favourably though slow internet connectivity was a problem.
\end{abstract}

Keywords: blended learning, material evaluation, course evaluation, English for academic purposes

\section{Introduction}

The medium of instruction in the Malaysian public school system is Malay. English is recognized as an important second language in view of its status as the lingua franca of the world, essential for economic advancement and international communication. Despite the emphasis on the importance of English, there has been a continual decline in English proficiency among school leavers. A contributing factor to this is the fact that a pass in English is not compulsory in any of the major public examinations. In an effort to reverse this trend, a revamped syllabus and a new English test, the SPM 1119, were introduced in 1997 (Lee \& Wong, 2006) to increase students' interest and motivation to learn English. Following this, the Malaysian University English Test (MUET), a standardized English proficiency test for academic purposes, was introduced in 1999. Students are required to take the test prior to entering public universities in Malaysia. There is no set minimum level across all universities required for entry, so students with very low proficiency continue to gain entry into insitutions of higher learning. However, some public universities have instituted minimum MUET band requirements for disciplines such as in Medicine, Dentistry and Law, and undergraduates in other disciplines are required to take special English proficiency courses to help them improve their English.

Students at the Faculty of Social Sciences and Humanities (FSSK) at Universiti Kebangsaan Malaysia (UKM) (The National University of Malaysia) are required to take an English for Academic Purposes (EAP) course labeled as English for Social Sciences (ESS) to enhance their academic skills in English. Students are expected to develop appropriate reading skills and strategies in order to comprehend academic texts relevant to their programmes. The course, which was conceptualized more than 10 year ago, underwent an evaluation in 2011 and was subsequently revamped. The committee found that the course book was too difficult for the lower proficiency students who comprised approximately $70 \%$ of the FSSH student population (2011/2012 intake figure). In addition, there was a general agreement that the reading selections were outdated and the activities did not really engage the students. A redesigned course session, which introduced a two-tier system to cater to students with diverse language abilities, was introduced in Semester 1, 2011/2012. The reading and writing thread of the series, $Q$ : Skills for Success published by Oxford University Press was chosen as the coursebook. A 
lower level text in the series was used for students of a lower proficiency level (MUET Bands 1 and 2) while a higher-level text was used for students of a higher proficiency level (MUET Bands 3 and above). The added feature of the new series is its online practice component, which was also utilized in the course. The decision to include the online practice was triggered by the awareness that technology plays an important role in the lives of the current batch of students. In the UKM context, studies by Thang et al.(in press) and Thang, Najihah, and Norizan (2012) found that generally students used technology for both recreational and academic purposes but their usage was confined to basic use. This study contends that the incorporation of the online component would increase the use of technology for educational purposes and this would have positive pedagogical impact on them.

The adoption of commercial materials for an English course is quite a common practice as they not only provide the course structure, syllabus and content, but also help standardize instructions (Harmer, 2004; Graves, 2000; Richards, 2001). In addition, established ELT publishers do take cognizance of the latest pedagogical development and thinking when conceptualizing these books. According to Lee (1999) course books should take into consideration the culture of the learners and authenticity of materials to real language environment. Kitao \& Kitao (1997) and Mahmood (2011) add that they should include a variety of topics to cater for students' diverse interests and this should be supported by illustrations that not only make the subject matter clear and interesting but also assist in helping learners comprehend the texts or the exercises given in the course book. Deuri (2012) further proposes that a good English course book should have materials that meet students' varied psychological needs and interests. Course books that provide supportive materials like CD, audio recording, test packages and workbooks that can be explored by students on their own, without teachers' instruction, are gaining popularity and publishers are beginning to work these into the latest books. However, it is not possible for publishers of ESL commercial materials to meet all these requirements, hence they normally strike for the middle path as they try to cater to most learners despite them being of diverse nationalities, ethnicities, cultural backgrounds, interests and proficiency levels. Most of the available work on instructional materials in Malaysia tend to be prescriptive, focusing on the 'how to' and are not based on empirical evidence. Very little research investigates the suitability of available commercial materials for local use. This study therefore attempts to fill this gap by investigating how students of an EAP course perceive the new instructional materials produced by a commercial publisher.

\section{Literature Review}

\subsection{Blended Learning}

The use of technology-based activities in the classroom is continually expanding and studies have shown that it facilitates students' learning considerably. An approach that has been generally accepted as one that incorporates "the best of both worlds" is the blended approach that combines traditional classroom learning with computer-mediated instruction. Kerres and DeWitt (2003) suggest that there should be a balance between traditional elements and technology to ensure positive learning outcomes. However, the composition of the integration varies according to individual context. Despite that there is a consensus that this approach should emphasise 'learning by doing' that encourages students to become active participants in knowledge construction (Watson, 2008; Graham, 2006; Rooney, 2003).

Previous studies investigating the effectiveness of the blended learning approach have reported that it meets the educational needs of students such as enhancing flexibility and convenience, allowing the attainment of higher achievement and attitude levels, and improving language learning skills as well as developing critical thinking skills (Lee \& Chong, 2007; Deghaidy \& Nouby, 2008; Wing \& Khe, 2011). However, studies have reported on students' apprehension, anxiety and confusion when interacting with online materials (Burgess, 2008; Baharun \& Porter, 2009). These experiences may happen when students do not have sufficient exposure to technological innovations in the classrooms. Furthermore, ambiguous instructions and guidelines may cause students to become lost and disengaged. The mixed findings suggest that innovations involving technology should be integrated appropriately and effectively within classrooms in order to improve and maximize students' learning outcomes. This study posits that the incorporation of self-access online reinforcement exercises would have positive pedagogical impact on them.

An earlier study on the newly introduced course books and the accompanying online component being evaluated in the present study was undertaken by Thang et al. (2012). The study investigated the perceptions of the effectiveness of the abovementioned course materials by a selected group of students. Data were collected through a qualitative approach involving the use of focus group interviews with 35 students. Each group comprised three to six members. Five groups consisted of lower proficiency (LP) students and four groups 
consisted of higher proficiency (HP) students. Besides getting feedback on whether the textbook and online component could meet their English learning needs, diverse interests and proficiency levels, the students were also asked about the problems and challenges that they faced using them.

The findings revealed that the less proficient (LP) students perceived the textbook favourably while the higher proficiency (HP) students' perceptions were mixed. The LP students appeared to have benefitted more from the materials and found the frequent reinforcement had given them a sense of accomplishment. In contrast, some HP students found the reading selections simple and repetitive. The online practice was also well received by the students. They acknowledged the benefits of learning via the online mode. However, their online experience was hampered by the poor internet connection on campus. Some students also complained that they had to do too many online exercises that they found tedious and boring. The researchers posited that a possible reason for the dissatisfaction of some students was the instructors' lack of flexibility and creativity in using the materials. Teachers appeared to be restricted by the structure and organization of the textbook and did not select content according to the needs and proficiency level of the students. The study also shows that the blended approach can help enhance the learning experience of the students but instructors and students need to know how to exploit the materials. The findings of this qualitative study will be compared to the present study which is quantitative in nature to find out to what extent the findings match.

\section{The Study}

\subsection{Research Questions}

The research questions of this study are the same as those of Thang et al (2012) to allow a comparison of the findings of these two studies.

1) What are the students' perceptions of the ESS course book and its online component in terms of the following:

a) Appropriateness for their English language needs?

b) Suitability for their level of English language proficiency?

c) Ability to cater to their diverse interests?

2) What are the challenges and problems they faced in using the course book and its online component?

\section{Methodology}

This study employed a quantitative approach in the form of a questionnaire consisting of 35 items designed to identify students' perceptions of the benefits and challenges towards the use of the new course book. Students were required to rate each item using a four-point Likert scale (ranging from $1=$ strongly disagree to $4=$ strongly agree). The questionnaires were distributed at the end of the semester to all students taking the ESS course. A total of 198 questionnaires (81\%) were returned. The collected data were tabulated and statistically analysed using descriptive and inferential statistical tools.

\subsection{Description of Sample Population}

The sample of this study consisted of 198 English for Social Sciences (ESS) students with English proficiency levels ranging from the lowest MUET Band 1 (very limited user) to Band 4 (competent user). These students were from the various programmes under the Faculty of Social Sciences and Humanities, UKM. Most of them were in their first or second year of studies.

\subsection{Description of the Course Materials}

The ESS course used levels 2 and 3 of the Q: Skills for Success: Reading and Writing course books published by Oxford University Press. Level 2 was used for students with MUET bands 1 and 2 and Level 3 was used for students with MUET band 3 and above. As a point of clarification, MUET results are reported in terms of bands with band 1 being the lowest, depicting the lowest level of proficiency in English and band 6 the highest, depicting the highest level of proficiency in English. Regarding the coursebooks, each level includes a student's books, a teacher's manual, a testing program and class audio CD-ROMs. Although the levels are different, both books share a common pedagogical framework or philosophy and are organised in the same manner. In addition, the reading and writing skills and sub-skills taught are similar albeit at different difficulty levels. The learning outcomes are clearly identified and explicit skill instructions are provided. On top of that, there are also questions linked to the topic of the unit that are described by the authors of the books as being designed to provide a "critical thinking framework" for the unit. In addition, the students' books contain reading texts that are said to be "current, academic and of high interest level to the learners". Another distinctive feature of the $Q$ : 
Skills for Success series is that the Student Book is complemented by the Q online practice. The students can utilize the online practice for 12 months by registering online using the access code provided in the course book. It provides additional practice and is thus akin to an online workbook. Besides, reinforcement exercises that parallel the course book, the audio versions of the reading texts are also available online. The online practice uses an automated marking system which enables students to check their answers instantly and track their own progress and teachers can also monitor their students' online work via the learning management system feature.

\section{Findings}

\subsection{Item Analysis of the Course Book}

An analysis of the students' perceptions of their course book using item analysis revealed that the top five items for both HP and LP students are the same though there are some slight differences in ranking order. The mean scores of these items incline towards 3 and above which means they "agree" with these statements. An analysis of the items indicated that both groups of students were of the opinion that their course book and its activities were interesting and had helped in improving their general and vocabulary knowledge.

Table 1. Top 5 items

\begin{tabular}{lclc}
\hline Bands 1 and 2 & Mean & Bands 3, 4 and 5 & Mean \\
\hline $\begin{array}{l}\text { Q12 - I find the reading passages improve } \\
\text { my general knowledge }\end{array}$ & 3.21 & $\begin{array}{l}\text { Q12 - I find the reading passages improve } \\
\text { my general knowledge }\end{array}$ & 3.31 \\
$\begin{array}{l}\text { Q11 - I find the reading passages interesting } \\
\text { Q7 - I feel that the activities and exercises in } \\
\text { the course book develop my English }\end{array}$ & 3.20 \\
$\begin{array}{l}\text { Q10 - The list of vocabulary at the end of } \\
\text { each unit helps me monitor my vocabulary } \\
\text { progress }\end{array}$ & 3.15 & $\begin{array}{l}\text { Q10 - The list of vocabulary at the end of } \\
\text { each unit helps me monitor my vocabulary } \\
\text { p3 - The discussion activities found in the }\end{array}$ & 3.19 \\
$\begin{array}{l}\text { course book are interesting } \\
\text { Q7 - I feel that the activities and exercises in } \\
\text { the course book develop my English }\end{array}$ & 2.06 & $\begin{array}{l}\text { Q3 - The discussion activities found in the } \\
\text { course book are interesting } \\
\text { Q11 - I find the reading passages interesting }\end{array}$ & 3.19 \\
\hline
\end{tabular}

An analysis of the bottom five items for each group showed that they are all negative items and the low mean scores of 2 and below indicated that they "disagreed" with all these statements. The bottom five items for both groups are also similar and only differ in ranking like the top five items. A scrutiny of the items demonstrated that the students disagreed that they had difficulty with the reading passages and exercises. In addition, they did not find the passages boring, unchallenging and unbeneficial to them.

Table 2. Bottom 5 items

\begin{tabular}{|c|c|c|c|}
\hline Bands 1 and 2 & Mean & Bands 3,4 and 5 & Mean \\
\hline $\begin{array}{l}\text { Q5 - I have difficulty doing the exercises } \\
\text { and activities in the course book. }\end{array}$ & 2.07 & $\begin{array}{l}\text { Q8 - The exercises and the activities in the } \\
\text { course book are not challenging. }\end{array}$ & 2.11 \\
\hline $\begin{array}{l}\text { Q2 - I have a lot of problems understanding } \\
\text { the reading passages in the course book. }\end{array}$ & 2.05 & $\begin{array}{l}\text { Q2 - I have a lot of problems understanding } \\
\text { the reading passages in the course book. }\end{array}$ & 1.86 \\
\hline $\begin{array}{l}\text { Q8 - The exercises and the activities in the } \\
\text { course book are not challenging. }\end{array}$ & 1.96 & $\begin{array}{l}\text { Q5 - I have difficulty doing the exercises } \\
\text { and activities in the course book. }\end{array}$ & 1.80 \\
\hline $\begin{array}{l}\text { Q4 - The topics/themes in the course book } \\
\text { are boring }\end{array}$ & 1.96 & $\begin{array}{l}\text { Q4 - The topics/themes in the course book } \\
\text { are boring }\end{array}$ & 1.80 \\
\hline $\begin{array}{l}\text { Q6 - I do not benefit from doing the } \\
\text { exercises and the activities in the course } \\
\text { book. }\end{array}$ & 1.78 & $\begin{array}{l}\text { Q6 - I do not benefit from doing the } \\
\text { exercises and the activities in the course } \\
\text { book. }\end{array}$ & 1.48 \\
\hline
\end{tabular}




\subsection{Item Analysis of the Online Component}

The mean scores of the top five items for both groups of students are all above 3 which means they "agree" with these statements. An analysis of the items revealed four similar items (Q14, Q31, Q32 and Q34) between the groups. Q14 is the only negative item and the high mean scores for this item for both groups mean that the students were unhappy that the online exercises took a long time to appear on the screen. This is a problem resulting from the slow internet connectivity. However, both groups were happy with the fact that the Q online exercises gave them an opportunity to learn at their own pace by tracking their own progress and marking their own exercises automatically. The final item for both groups reiterated their approval of Q online practice. The LP group felt that it should be offered again the following semester (Q35) while the HP group agreed that it helped to reinforce what they had learnt in class $(\mathrm{Q} 18)$.

Table 3. Top 5 items

\begin{tabular}{llll}
\hline Bands 1 and 2 & Mean & Bands 3, 4 and 5 & Mean \\
\hline $\begin{array}{l}\text { Q14 - I have to wait for a long time for the } \\
\text { Q online exercises to appear on the screen. }\end{array}$ & 3.44 & $\begin{array}{l}\text { Q31 - I like the fact that my Q online } \\
\text { exercises are marked automatically. }\end{array}$ & 3.37 \\
$\begin{array}{l}\text { Q34 - The Q online exercises allow me to } \\
\text { learn at my own pace. }\end{array}$ & 3.09 & $\begin{array}{l}\text { Q32 - I like Q online practice because I can } \\
\text { track my own progress. }\end{array}$ & 3.28 \\
$\begin{array}{l}\text { Q31 - I like the fact that my Q online } \\
\text { exercises are marked automatically. }\end{array}$ & 3.09 & $\begin{array}{l}\text { Q34 - The Q online exercises allow me to } \\
\text { learn at my own pace. }\end{array}$ & 3.26 \\
$\begin{array}{l}\text { Q32 - I like Q online practice because I can } \\
\text { track my own progress. }\end{array}$ & 3.07 & $\begin{array}{l}\text { Q14 - I have to wait for a long time for the } \\
\text { Q online exercises to appear on the screen. }\end{array}$ & 3.26 \\
$\begin{array}{l}\text { Q35 - The activities in the Q online should } \\
\text { be continued for next semester }\end{array}$ & 3.07 & $\begin{array}{l}\text { Q18 - I find the Q online exercises help to } \\
\text { reinforce what was taught in class }\end{array}$ & 3.18 \\
\hline
\end{tabular}

The bottom five items contain a mix of positive and negative statements. The two positive items, Q16 and Q26, are common to both groups. The mean scores for these two items are closer to 2 than 3 . This finding suggests a greater extent of disagreement than agreement. Thus, it would appear both groups were inclined to disagree that doing the exercises online was better than doing them in a workbook and they tend not to follow class activities via $\mathrm{Q}$ online activities. However, their responses to the negative statements contradicted these findings. Both groups disagreed that they did not enjoy working on the $\mathrm{Q}$ online exercises and did them just for the marks. LP students also disagreed that they did not listen to the audio version of the Q online reading passages and HP students disagreed that they found the exercises repetitive.

Table 4. Bottom 5 items

\begin{tabular}{|c|c|c|c|}
\hline Bands 1 and 2 & Mean & Bands 3,4 and 5 & Mean \\
\hline $\begin{array}{l}\text { Q16 - I always follow up the class activities } \\
\text { with the Q online activities. }\end{array}$ & 2.48 & $\begin{array}{l}\text { Q26 - I think doing online English exercises } \\
\text { is better than using a workbook. }\end{array}$ & 2.36 \\
\hline $\begin{array}{l}\text { Q26 - I think doing online English exercises } \\
\text { is better than using a workbook. }\end{array}$ & 2.44 & Q28 - I find that the exercises are repetitive & 2.34 \\
\hline $\begin{array}{l}\text { Q24 - I do not listen to the audio version of } \\
\text { the reading passages on Q online. }\end{array}$ & 2.43 & $\begin{array}{l}\text { Q16 - I always follow up the class activities } \\
\text { with the Q online activities. }\end{array}$ & 2.25 \\
\hline $\begin{array}{l}\text { Q17 - I do not enjoy working on the Q } \\
\text { online exercise }\end{array}$ & 2.33 & $\begin{array}{l}\text { Q19 - I only do the Q online exercises } \\
\text { because marks are given }\end{array}$ & 2.19 \\
\hline $\begin{array}{l}\text { Q19 - I only do the Q online exercises } \\
\text { because marks are given }\end{array}$ & 2.19 & $\begin{array}{l}\text { Q17 - I do not enjoy working on the Q } \\
\text { online exercise }\end{array}$ & 1.99 \\
\hline
\end{tabular}




\subsection{Comparison of Mean Scores}

\subsubsection{Students' Perceptions of the Course Book}

Inferential statistics in the form of a one-way analysis of variance (ANOVA) was undertaken to compare the mean scores of the two groups of students' perceptions of the course book to determine reliability and validity of the descriptive findings. First, the internal consistency of the 12 items on students' perceptions of the course book was determined using the Cronbach's Alpha reliability test. The value is 0.72 which confirms reliability of the grouping. The mean scores of the 12 items for the HP and LP groups were compared using ANOVA. The results revealed that the mean score of the HP group (3.096) is significantly higher than the mean score of the LP group $(2.980)[\mathrm{p}<0.05 ; \mathrm{F}(\mathrm{df})=7.43(1 / 194)]$ which means that the HP group viewed the course book more favourably than the LP group.

\subsubsection{Students' Perceptions of the Online Component}

ANOVA was also used to compare the mean scores of the two groups of students' perceptions of the Q online exercises. The internal consistency of the 23 items on students' perceptions of the Q online exercises, measured using the Cronbach's Alpha reliability test, indicated a value of 0.87 which confirms reliability of the grouping. The mean scores of the 23 items for the HP and LP groups were compared using ANOVA. The results revealed that the mean score of the HP group (2.709) is not significantly higher than the mean score of the LP group (2.777) $[\mathrm{p}<0.05 ; \mathrm{F}(\mathrm{df})=1.474(1 / 194)]$ which means both groups did not have different perceptions regarding the $\mathrm{Q}$ online exercises.

\section{Discussion and Conclusion}

Item analysis of the items indicated that both groups of students had a favourable opinion of the course book and its activities towards meeting their language and personal needs. Inferential statistics revealed that the HP group viewed the course book more favourably than the LP group. These findings contradicted those from the qualitative study by Thang et al. (2012). Their findings revealed that the LP students' perceptions of the textbook were favourable while the HP students' perceptions were mixed. This contradiction is very interesting and can be interpreted in two ways. First, it can be seen as an indication that the number of HP students who found the course book problematic to be less than those who found it to be beneficial. However, among these students a small group had strong negative views regarding the content of the book. Thang et al. (ibid.) identified this group as students from the English Language Studies and English Literature programmes whose medium of instruction is primarily in English unlike students from the other programmes whose medium of instruction is in Bahasa Malaysia (the Malay Language). Second, it was possible that the LP students were more reluctant to give strong positive affirmations when answering the questionnaire survey. Both explanations are plausible; hence it is safe to conclude that both groups perceived their course books to be beneficial to a large extent; however there were a small group of students who felt strongly against them.

With regard to the $\mathrm{Q}$ online exercises, both groups of students were unhappy with the slow internet connectivity. This finding was also found in the qualitative study by Thang et al. (ibid.) This study further indicated that the students as a whole were happy with this new mode of learning for giving them the opportunity to learn at their own pace and also for allowing them to track their own progress which is possible through the automated marking system. However, the small number of students who were unhappy with it because of the volume of exercise and its repetitive nature as revealed in Thang et al.'s study (ibid.) cannot be ignored which suggests the need to consider using more challenging and thought-provoking texts to overcome this problem.

Inferential statistics of this study revealed that both groups did not have different perceptions regarding the Q online exercises and this was discovered in Thang et al.'s (ibid.) study. Thus, overall this study confirmed Thang et al.'s (ibid.) findings that the blended approach has effectively enhanced the students' learning experiences and helped to meet their language and personal needs. The findings of this study are in line with those taken in other contexts such as the studies by Lee and Chong (2007), Deghaidy and Nouby (2008), and Wing and Khe (2011). However, the issue of technological problems is worrying and needs to be addressed swiftly to ensure long-term effectiveness and sustainability of this mode of learning.

\section{Acknowledgements}

This work was supported by a research grant provided by Universiti Kebangsaan Malaysia (UKM-PTS-2011-160).

\section{References}

Baharun, N., \& Porter, A. (2009). Teaching statistics using a blended approach: integrating technology-based 
resources. In Same Places, different spaces. Proceedings ascilite Auckland 2009 (pp. 40-48).

Burgess, J. (2008). Is a blended learning approach suitable for mature, part-time finance students? The Electronic Journal of e-Learning, 6(2), 131-138.

Deghaidy, H. E., \& Nouby, A. (2008). Effectiveness of a blend-ed e-learning cooperative approach in an Egyptian teacher education programme. Computers \& Education, 51, 988-1006. http://dx.doi.org/10.1016/j.compedu.2007.10.001

Deuri, C. (2012). An evaluative study of text book in English at higher secondary level. International Journal of Science, Environment and Technology, 1(1), 24-28.

Dziuban, C. D., Hartman, J. L., \& Moskal, P. D. (2004). Blended learning. Educause Research Bulletin, 7, 2-12.

Graham, C. R. (2006). Blended learning systems: Definitions, current trends, and future directions. In C. J. Bonk, \& C. R. Graham (Eds.), The handbook of blended learning: Global perspectives, local design (pp. 3-21). San Francisco: Pfeiffer.

Graves, K. (2000). Designing language courses. Canada: Heinle \& Heinle Publishers.

Harmer, J. (2004). How to use textbooks: How to teach English. Kuala Lumpur, Malaysia: Longman.

Kerres, M., \& C. De Witt. (2003). A didactical framework for the design of blended learning arrangements. Journal of Educational Media, 28(2-3), 101-113. http://dx.doi.org/10.1080/1358165032000165653

Kitao, K., \& Kitao, S. (1997). Selecting and developing teaching/learning materials. The Internet TESL Journal, 4(4). Retrieved from http://iteslj.org/Articles/Kitao-Materials.html

Lee, K. C., \& Chong, P. M. (2007). An observational study on blended learning for Japanese language studies. In Fong, J., \& Wang, F. L. (Eds.), Blended learning (pp. 88-100). Edinburgh: Pearson.

Lee, King Siong, \& Wong, Fook Fei. (2006). Washback effects of a new test on teaching: A Malaysian perspective. In Shanta Nair-Venugopal et al. (Eds.), 2006 Writing the past into the present: Reflections of 35 years of scholarship in language and literary studies (pp. 88-101). Bangi: Penerbit UKM.

Lee, Zong-Yue. (1999). Tips for selecting teaching materials. Cave English Teaching, 21, 21-23.

Mahmood, K. (2011). Conformity to quality characteristics of textbooks: The illusion of textbook evaluation in Pakistan. Journal of Research and Reflections in Education, 5(2), 170-190.

Richards, J. C. (2001). Curriculum development in language teaching. Cambridge: Cambridge University Press. http://dx.doi.org/10.1017/CBO9780511667220

Rooney, J. E. (2003). Knowledge infusion: Blending learning opportunities to enhance educational programming and meetings. Management Association, 55(5), 26-32.

Thang, S. M., Najihah, M., \& Norizan A. R. (2012). The use of wireless technology in UKM: Challenges faced and its impact on English language learning. 3L: The Southeast Asian Journal of English Language Studies, 18(1), 129-143.

Thang, S. M., Radha, N., Wong, F. F., Nurjanah, M. J., \& Zaini, A. (In Press). Investigating the ICT needs of 'digital natives' in the learning of English at a public university in Malaysia. Scopus Procedia.

Thang, S. M., Wong, F. F., Noorizah, M. N., Rosniah, M., Najihah, M., \& Kemboja, I. (2012). Using a blended approach to teach English for academic purposes: Malaysian students' perceptions of redesigned course materials. International Journal of Pedagogies and Learning, 7(2), 142-153. http://dx.doi.org/10.5172/ijpl.2012.7.2.142

The Malaysian University English Test: Regulations, test specifications, format and sample questions. (2006). Kuala Lumpur: Malaysian Examinations Council.

Watson, J. (2008). Blended learning: The convergence of online and face-to-face education. Vienna, VA: North American Council for Online Learning.

Whitelock, D., \& Jefts, A. (2003). Editorial: Journal of Educational Media special issue on blended learning. Journal of Educational Media, 28(2-3), 99-100. http://dx.doi.org/10.1080/1358165032000177407

Wing, S. C., \& Khe, F. H. (2011). Design and evaluation of two blended learning approaches: Lessons learned. $\begin{array}{lllll}\text { Australasian Journal of } & \text { Educational } & \text { Technology, } & \text { 27(8), }\end{array}$ http://dx.doi.org/10.1007/978-1-4614-2370-6_1 